\title{
EDUCATIONAL MANAGEMENT FROM PSYCHOSOCIAL PERSPECTIVE
}

\author{
Assist. Oprea Valentin Bușu, PhD \\ University of Craiova \\ Teaching Staff Training Department \\ Craiova, Romania \\ Bianca Teodorescu, PhD Student \\ University of Craiova \\ Faculty of Letters \\ Craiova, Romania
}

\begin{abstract}
This article is based on research about the class management and how we can better understand its importance. There is a series of experiments based on manager's psychology that are imposing as well in the educational system. Every person who works in the field of education must see these experiments as a way to create a better relationship between teacher and students. A better knowing of the class leads the teacher to guidance his students to a good path in learning and education.
\end{abstract}

JEL Classification: 10, 12

\section{Keywords: class management, psychology, manager}

\section{INTRODUCTION}

For a class management to have an order, the teacher has to implement his knowledge on his students. But how a manager of a class can create a good communication with his students? Based on Patrick Amar's research on how the experiments from the point of view of manager's psychology can achieve a better level of work, we considered that a class of students can be a taught task for every teacher if he does not know the particularities on class leadership. Every teacher must understand that a class of students will see him like a manager if he is a good coordinator.

For a teacher to be a good manager, he can apply some experiments on his class of students. It is very important for a teacher to know his students, to understand them and to reach to know every person from the class. A teacher's efficiency as a class manager impose the ability to order, to transform and to adapt his capacities and knowledge in all the new situations that he finds in the school. A class manager must have some qualities as: charisma, flexibility, integrity that will help him create a good communication with his students.

\section{OBJECTIVES}

Our objectives is to find the result of the experiments cased on manager's psychology and to use them in the interest of a better management in the class. We consider that is necessary for any person from the educational system to impose these experiments in their arsenal of knowledge.

Our purpose is to inform every teacher to understand the importance of these experiments cased on manager's psychology and to apply them on their class. There is a 
series of benefits in the management plan and if they are applied in the class, the results of these experiments will help a teacher to differentiate from the other teachers.

\section{METHODOLOGY}

This article is based on a meta-analytic method in which we manage to create our research from the perspective of some important authors from educational field. In our research, we find Patrick Amar's work as an excellent part of understanding how the class management can be improved in order to achieve success among students. Patrick Amars book ,50 experiments case on manager psychology" is representing a series of very interesting information regarding on how a manager can succeed at his work. Based on this, we suggested that our research can apply these experiments also in the field of education where every class have a teacher who is preferred to be a good manager. A class of students with a good manager will be a successful one.

\section{Class MANAGEMENT}

The management is composed by a series of organized activities in which the person who has the function to lead must glorifies the human resources of the group or organization. Thus, class management establishes some rules that are following some conditions in order for the students to understand the importance of education and to glorify the learning.

There are some experiments who are representing a benefit for every class of students if the teacher applies them correctly. The American researcher, Leon Frestinger, developed a theory of cognitive approach that is one of the fundamental concept of social psychology allowing the interpretation of some behaviours who are not entirely rational. Cognitive approach represents a state of psychology discomfort who can be felt by a person as incompatible beliefs. People will try to cut internal tensions through a mechanism of elimination of some incompatible thoughts. This theory highlights the difficulty changing a person whose belief is very strong. Teachers can put all the efforts in creating an expensive strategy and ignoring the other facts that are in contradictory with the wrong analyze.

\section{Pygmalion Effect}

„If the teacher is considering their students more intelligent than they are, will they become actually more intelligent?", the question was asked in the book Pygmalion à l'école (1978) by the authors Robert Rosenthal and Lenore Jacobson.

We all know what the Pygmalion effect is, but it is important to understand that the self realized prophecy is sending the person in a way which it can be transformed or changed according to the expectations. This theory suggests that we can behave with someone as he can is smart in order for him to have real changes to become smarter. Also, it suggests that it is important for a person to stay open to the other without prejudices. For the other to become as you see him, it is important to confront him.

The commitment theory and the door foot

In a class, a teacher is facing different behaviours and in order to make the students to listen what he says, he must motivate them and convince them to do something that the manager (teacher) wants to. Another experiment is given by the commitment theory in which is imposing some attitude changes that are necessary for a person to make some actions in which he engaged in the wanted path (Popescu, 2008; Popescu, 2015). This commitment theory prove to us that the teacher's interest is to 
follow a leadership of conviction where the feeling of commitment of a person can be maximized by the idea of free will.

\section{The fundamental mistake of attribution}

A teacher is a machine of thinking who have the managerial activity to make decisions in the class (Cristea, 2004; Frăsineanu, 2014). In the moment when a teacher is observing a certain behavior at a person, he may assign an internal cause (his personality) or an external cause about the situation of the person.

Diversity and intercultural management

A class of students is composed by a group of people who many times, they are not embrace the same cultural vales. For a teacher it is very important to understand that some students are not believing in the same religion as him, also the fact that their culture can be a lot different from his (Cojocariu, 2004; Popescu, 2013). Because of that, a teacher is a good manager if he empathizes with his students and reaches to an intercultural understanding.

\section{Managers stress}

Teachers are put in a stress condition systematically. The negative consequences of stress can be observed on three levels: physical, psychological and behavioural. For a teacher to pass through stress there are some techniques anti-stress which their purpose is to decrease stress and the raise the capacity of the person to manage it.

\section{Personality problems}

For a teacher, the problem of diverse personalities in a group can be managed to identify the knowledge of the class, to understand the needs of students which it allows an adaptation to the class personality.

\section{Leadership theories}

A teacher who is a good leader has the capacity to influence the behavior of his students in order to achieve good results on class. For a leader to be efficient, he needs to have a flexibility in his behaviour which it is necessary in adapting to the situation of class.

\section{Normative influence and conformist}

The pressure of conformist is more and more powerful as the group is composed by more than two or three persons. A class is facing the phenomena of normalization in which every person from the group are aligning to common rules. The teacher, in our case, must create a special activity in which students' behaviour will change and will not adapt to a conformist zone.

A teacher who is a good manager must be seen as a leader in the class. The communication with his students has to be great in the way that he will attract the students to the study. The manager, as in our case, the teacher himself, must glorify the educative relation that he has with his students and to make sure that they understand the importance of learning. Class management targets the administration activity (Călin, 2010; Călin, 2015; Landicho, 2016). Also, the teacher in a class must know his objectives, programs and the perspective regarding the path that the class is taken. One of the most important actions that a teacher will put in practice in a class is the cooperation (Popescu \& Stefan, 2014; Teodorescu \& Colhon, 2015). His students must cooperate to achieve good results in time as a group. Communication between a teacher and his students have to be open, stable where every person from the group has the same norms and values. 


\section{CONCLUSION}

The experiments that are applied in a class by a teacher will put a difference between his group and the other class, also will face the difference between him and other teachers. There are some functions that every teacher must have: prediction, organization, coordination, training and control. These functions can create a successful control over the students and through that, teacher will allow to have a good communication with all the class, drawing that he is the manager of the class.

\section{REFERENGES}

1. Amar, P.

2. Călin, A.R.

3. Călin, R.A. . Self-Education through Web-Searching-An Exploratory Study. Social Sciences and Education Research Review, 2(2), 47-58, 2015

4. Cojocariu, Introducere în managementul educaţiei. Editura Didactică şi V.M.

5. Cristea, $S$. Pedagogică, 2004

5. 2004

6. Landicho, J. A. Voisee Communicator: An Android Mobile Application for Hearingimpaired and Blind Communications. International Journal of Interactive Mobile Technologies (iJIM), 10(4), 26-31, 2016

7. Frăsineanu, Pedagogie. Managementul cla sei de elevi. Craiova: Sitech, 2014 E.S.

8. Popescu, A.M. Orientations and Tendencies In The Didactic Methodology for The Initial Formation of The Teaching Staff. Annals of The University of Craiova-Series Geography, 11, 112-116, 2008

9. Popescu, A.M. Prescriptive Models of Intervention Strategy Choice of Manager in the Resolution of Conflict Moods. Procedia-Social and Behavioral Sciences, 180, 197-202, 2015

10. Popescu, Formarea psihopedagogică a profesorului. Ipoteze şi soluţii A.M.(coord.) aplicative. Sarcini. Modele şi instrumente. Nivelul II. Craiova: Editura Sitech, 2013

11. Popescu, A. M., Training the educator for methodological alternatives and paradigm \& Stefan, M. A. changes in education. Revista de Științe Politice, (43), 171-183, 2014

12. Rosenthal, R. Pygmalion à l'école: l'attente du maître et le développement A., \& Jacobson, intellectuel des élèves. Casterman. 1978 L.

13. Teodorescu, C., Creation of Electronic Linguistic Resources. The Acquisition of \& Colhon, M. Transversal Skills by MA Students in Letters. Transversal Skills Development in Modern Teaching Practice, 86, 171, 2008 